\title{
The Use of aVideo Camera in Learning Process of Polite Talk at Kindergarten in Padang
}

\author{
Nenny Mahyuddin \\ Early Childhood Education \\ Universitas Negeri Padang \\ Padang, Indonesia \\ nenny.mahyuddinpaud@gmail.com
}

\begin{abstract}
This research aimed to improve the quality of learning at kindergartens through observations by the video camera in the classroom activities. The subjects of the research were the teacher candidates studying the major of early childhood education. The method used was qualitative with the data collection through observation, interviews and documentation. The results showed that there had been kindergartens using video camera in the classrooms and some had also been using the camera manually. The teachers observed the results of the classroom study as a means of evaluating themselves after teaching. It is expected that after applying this method, teachers would be more optimal in teaching early childhood students.
\end{abstract}

\section{Keywords—learning politeness; video camera; kindergarten}

\section{INTRODUCTION}

The learning process on the level of early childhood education has not been effectively conducted yet. In general, at the institutions of early childhood, the ratio of educators and students is 1:30. Considering the amount of the students in a class, it was believed that not all children could easily be noticed and observed by the teacher. Learners in the early age child-hood have diverse behaviors. Based on observations and interviews with several sources in the field, it was found that the majority of teachers were less able to intensively monitor during the process of education. Based on the interview between the researcher with the teachers of RahmaAbadi Kindergarten of Padang (April 2015) it was mentioned that the big number of children in a class caused many troubles for teachers to keep an eye on their talks. The lack of scrutiny against the students certainly made an impact on the deviation of behavior of the students. Women's empowerment Minister Linda Amalia Sari Gumelar (compass, 2014) mentioned that the level of violence committed by children to other children had al-ready been at the worrying levels and needed to be brought to the attention of all components. The condition occurs due to a lack of supervision of the school; both schools' principals and teachers. Violence perpetrated by children to other children was believed to happen frequently and the school gave less attention to the issue. This condition happened also be-cause of the amount of students was pretty much bigger than the number of teachers and the broad schools' complexes.

Next, the supervision of students in the classroom also became an obstacle. The number of students who were very big in the class i.e. more than 15 children led teachers to be very less intensive in monitoring both positive and negative moral progresses of their learners. Regarding to the number of teachers and the issues appeared from the comparison with the amount of students, the presence of a recording device was needed to record the activities that later be used to analyze and study by the teachers so the important actions towards certain behaviors or happenings could be taken by the teachers in the learning process.

The recording device is used to assist analysis of teachers in monitoring the activities and students' behavior in learning, especially for early childhood. Since the function of video camera can save images of the moving objects, in this case, students' behavior in the learning process to be analyzed so that teachers could observe the development of these early age children during the school day.

This video was not used a means for teachers in the delivery of lesson, but is a means for teachers to record the learning process to further be analyzed by both the teacher and the colleagues.

In this research, the use of video media as one of the learning media, focused as a tool for help record all information and activities of students in learning. The results of the subsequent recordings used was able to improve optimization of the development and potential in early childhood.

Regarding to the advantages of video as one of learning tools, using them was also to see the process of learning politeness talk in children.

Early childhood have different characteristic from adults, since each of early children grows in many different ways. Early childhood have characteristics of; 1) egocentric, naive 2) have a social relationship with objects and human nature simply and primitively, 3) physical and spiritual unity is almost inseparable as a totality, 4) attitude of life physiognomies, i.e. the child directly define the attributes/properties of the physical or anti-material to any comprehension[1].

Another opinion about early childhood characteristics are: 1) a child has a great curiosity, 2) each is a unique individual, 3) loves to Fanta-size and imagine, 4) is in the potential time to learn, 5) has the attitude of egocentric, 6) has a short time concentration, 7) is part of social beings[2]. Meanwhile, the Rusdinal (2005:16) added that the characteristics of children aged 5-7 years were as followed: 1) during the pre- 
operational, learning through concrete experiences and with orientation and goals for a moment, 2) a child likes to mention the names of the surrounding objects and defines the words, 3) a child learns through oral language and rapidly grows at this time, 4) a child needs structured, clearer and specific activities[3].

Based on the characteristics that have been mentioned above, then it can be known that children aged 4-6 years (Group B) can do a coordinated movement. Their language development is already good and they are able to interact socially. This age is also a sensitive time for the children to learn the language. With the coordination of the movement, children were able to move eyes and hands to realize his imagination into the shape of the image, so the use of images of works of children can help improve the ability to talk.

Based on explanation above then the purpose of this study is to describe:

a. His use of video camera in learning politeness talk on children aged 4-6 years in kindergartens.

b. To generate a scientific article to be published in accredited international journals.

\section{METHOD}

This research used qualitative research methods with the descriptive-designed-research. Descriptive research is one of the types of research that aims to describe systematically, factual and accurate about facts and natures of a particular population or try to describe the phenomenon in detail[4].

Descriptive research is used when aiming to describe or explain the events and happenings that exist at the present[5].

The subjects of this research are two institutions, MekarMelati, located in the down town, and RahmahAbadi, located in the suburb of Padang.

Type of data collection in this research was primary data, i.e. data is directly retrieved from the subject of the research. In this research, primary data were derived from the first source that teacher about the utilization of media video camera early childhood. The sources of the data in this study were two early childhood schools established by The State University of Padang (MekarMelati and RahmahAbadi).

Technique of the data collection in this study was conducted by observation, interview and question forms. The results of the observations addressed to obtain data about the location of the actual research. The interview was intended to deepen the results of the observation and question forms were used to obtain preliminary data about the objects of the research. The data will then be analyzed in qualitative descriptive.

The techniques of data analysis in this study was done qualitatively. Qualitative analysis is well-known as the technique of Miles and Huberman that was begun by the data reduction, display data until the conclusion taking.

\section{RESUlT AND DisCUSS \\ A. The Process of Learning Politeness Talk in Early Childhood}

Based on the research conducted on this discussion, the researcher focused on the process of learning politeness talk in children aged 4-6 years, the use of media and learning strategies as well as in early childhood learning process based on children's characters at this age. a. The effectiveness of the use of media and learning strategies

Based on research conducted at the two schools, it was observed that the use of the video camera as a tool was important. The use of the tools in the learning process was crucial to help process of learning politeness talk.

In the process of learning, it is a very important tool used in the learning process. Video camera serves to capture an object or specific events. The important events or objects that can be enshrined with rare photos, film, or recorded via video or audio, then it can be saved and can be used when needed. In this context the use of the video camera aimed to record the process of learning at school time to be analyzed in order to increase learning's results.

b. Early Childhood Learning

Based on the observations made, the researchers found that optimal learning activities were already underway, starting from the preliminary activities, core activities, and breaks and closing activities.

In learning process, to plan outdoor activities (outdoor) imaginative and exploratory, the teachers age the opportunity to the children to try (learning by doing), the students studied with natural materials and residual materials, and children got teachers' attention quite well (40\%).

\section{$B$. The use of video camera towards language development}

observation on early childhood

Based on the results of the research conducted, it is seen the use of video camera implicates positivity towards language development observation in early childhood. The implications of the use of the video camera in early childhood services can be seen on the three fields i.e. fields of learning process, the use of media and learning strategies and processes learning in early childhood.

a. Learning process in early childhood

The results of the analysis on the use of the video camera in early childhood learning at MekarMelati and RahmahAbadi were followed up with supervision to that school. During the supervision it was conducted interviews, observation, questioning and charging. In general, the results of supervision to the schools as the implications of the use of the video camera to improved educational services for early childhood was that the language learners at the two schools were well done on aspects of understanding the teachers' questions, orders, speaking in polite to friends and teachers. Through observation/observation, interviews with parents of children and asked the child what he liked and what he did not like. Similarly in developing potential, skills, talents, interests, intelligent characters and religious teachers did well through the provision of facilities, granting appropriate age progression, and the granting of motivation. While assessing the potential, skills, talents, interests, intelligent characters and religions, teacher performed well enough to make the assessment objective.

This method helped learners assess social relations in a healthy, effective and intelligent character with peers, teachers also did well through the assessment objective. To help students develop healthy social relationships, effective and intelligent characters with peers, teachers also conducted 
through giving the motivations, reward, and did cooperation with parents.

To develop in scientific field in terms of helping learners understand scientific learning activities done with good teachers is to inform a variety of types of science and technology by the use the media, TV, and a visit to the nearby working places (such as to the post office and fire fighter basecamp). Likewise, in helping the learners choose the place field trip (the location of which will be visited in accordance with the theme), teachers did it well by the giving of information, visits or field trip, visit according to the theme, telling about the results of the visit, playing roles with a wide range of jobs and professions visited, would also train the habit of task completion and responsibility.

b. The use of learning strategies and media

Video camera served as a tool in the learning process to help teachers analyze the learn-ing done and to assist colleagues and friends of the supervisors or the team of experts. Teachers could analyze learning that they did in class so that they can take action to fix regarding what they observe in the learning process. Anythin done in the learning process can be seen by teachers in detail through the resulting video which then can be analyzed. In the process of learning directly, sometimes teachers are also the important objects of study. By using video as a means to record the learning outcome will be more optimal.

The use of video camera was very much to help the process of supervision of teachers. Teachers could analyze the use of the materials and strategies in learning through observations made on the video camera. The use of videos already implicates to increased ability of teach-ers in utilizing media and optimizing the use of learning strategies. Through the activities of administering the supervision of researchers to the teachers pointed out that the use of the learning strategies already varies and depends on the selected theme of learning so that the process of tutoring early childhood was already undergone optimally.

The main purpose of coaching efforts in kindergarten is help-ing children in order to help themselves to hold personal and social adjustments so that the children are able to pass through a period of transition [6]. The process meant here is the changing of world of childhood into adulthood. Learning strategies recommended at the early child-hood learning are thematic with system providing the learning process into one specific theme. In this context, every day teachers are encouraged to associate learning activities into one specific themes that have been selected as to facilitate students to capture the learning.

The theme of learning can be applied since the beginning of the learning activities, from preliminary activities, the core, until the cover, so that the learning processes go into one whole unified. The observations through video showed that learning activities had not been carried out coherently by the teacher. Although there were a few activities done by students since the beginning of the classroom activities, there were less activities referred to one par-ticular theme, both in the form of songs, up to physical and motoric activities of the students. After learning activities with researcher's supervision, they started to show the results by making such activities coherently with one specific theme.
Special media learning, from the results of observations made showed that teachers relied on simple media created by teachers, which were generally made of paper and other materials. According to the theory of the media, the more real the shape, the more effect to the child and meaningful learning experiences for the child. In this context, some themes for learning such as hygiene, researcher conducted by using a real media contained around the neighborhood of students such as a broom, a tub of trash, garbage, sweep of tally, feather duster and others. So that the child could communicate through speaking manners to teachers and friends in kindergarten naturally when playing together.

\section{CONCLUSION}

Based on the results of discussed above, of research on the use of the video camera on learning and the implications for services in early childhood (4-6), the following conclusions were obtained:

1. The use of video cameras to improve observations in the learning process of early childhood at schools was reviewed from three aspects namely learning strategies, use of media and processes early childhood learning and scientific learning. The review of the use proved to be quite effective because of an increase in a number of indicators as followed:

a. The useof media and learning strategies. The use of media and learning strategies had in-creased the ability of speaking manners in children. At the beginning of the learning process, before the use of video, the information obtained that the use of learning strategies and learning media was dominant in both categories. After the use, it was noticed an increase in super-vision activities i.e. strengthening speak according the themes of learning that was conducted as well as real media utilization in the learning process.

b. The process of learning in early childhood.Early childhood learning process had already been proceeded on effective introduction, core activity and rest, but still there had been constraints on the activities of the cover. After the supervision activities, teachers were encouraged to improve the closing of the learning activities as a whole effective process.

c. Scientific learning to the students. In general, teachers had already been able to guide kids to talk politely. After being given supervision based on the analysis carried out in accordance with the results of the previous video camera footage then speaking manners guidance for early childhood experience increased.

2. The use of video cameras to improve the guidelines for the teacher to correct anything that had occurred in the process of learning in order to teach students to speak politely and to also apply the manners among the teachers at the kindergartens. It could happen due to the recording of the video camera let the teacher be able to analyze and conduct supervision activities towards learning politeness talk in children. 


\section{References}

[1] Ka. KArtini, Pengantar Penelitian Sosial. Bandung: Mandar Maju, 1990.

[2] S. Hartati, "Perkembangan belajar pada anak usia dini," Depdiknas Dirjen Dikti. Jakarta, 2005.

[3] Rusdinal, Pengelolaan Kelas di Taman Kanak-kanak. Jakarta: Depdiknas Dikjen Pendidikan Tinggi Direktorat Pembinaan Pendidikan Tenaga Kependidikan Dan Ketenagaan Perguruan Tinggi, 2005 .

[4] A. M. Yusuf, "Metodologi Penelitian," Padang: FIP-UNP, 2005.

[5] N. Sudiana, Dasar-dasar proses belajar mengajar. PT Sinar Baru Algensindo, 1989.

[6] A. Ahmadi and A. Rohani, Bimbingan dan konseling di sekolah. PT Rineka Cipta, 1991. 